\title{
„Osoba polskiego pochodzenia”. Terminologiczno-prawny aspekt represji po powstaniu styczniowym na Ziemiach Zabranych
}

Zarys treści: Artykuł przedstawia problem, jaki miały władze państwa rosyjskiego różnych szczebli z określeniem, kogo należy karać za udział w powstaniu styczniowym na ziemiach litewsko-białorusko-ukraińskich. Wszystkie próby sprecyzowania przedmiotu represji, podejmowane w latach 1865-1914, zakończyły się niepowodzeniem. Autor analizuje najważniejsze działania władz centralnych i administracji terenowej mające na celu wskazanie cech charakteryzujących „osobę polskiego pochodzenia”.

Outline of content: The article presents the problem dealt with by the Russian state authorities of various levels how to determine who should be punished for participating in the January Uprising in the Lithuanian-Belarusian-Ukrainian territories. All attempts to precisely define the subject of reprisals undertaken in 1865-1914 were unsuccessful. The author analyses the most important activities of the state authorities and local administration aimed at determining the characteristics of a "person of Polish descent".

Słowa kluczowe: Ziemie Zabrane, represje popowstaniowe, aspekty prawne, kontrybucje, zakaz obrotu ziemią, kto jest Polakiem?

Keywords: Taken Lands, post-uprising reprisals, legal aspects, contributions, land sales ban, who is a Pole?

Przez cały wiek XIX i początek XX, aż do upadku caratu, rosyjskie władze państwowe, mimo podejmowanych wielu prób, nigdy nie doprowadziły do końca sprawy precyzyjnego, jurydycznego uregulowania terminu „osoba polskiego pochodzenia”, który stosowany był w ogromnej liczbie różnorodnych aktów prawnych.

Jeszcze trwało powstanie, a już władze rosyjskie zaczęły stosować zasadę odpowiedzialności zbiorowej za jego wywołanie. Kontrybucja, nazwana przez Michała 
Murawiewa „временный процентный сбор”, została wprowadzona uchwałą Komitetu Zachodniego 8 lipca 1863 r. ${ }^{1}$ i obejmowała wszystkie majątki ziemskie, bez względu na narodowość ich właściciela. Oznaczało to, że 10\% kontrybucji od pełnego rocznego dochodu było formą represji opartą na kryterium społecznym, stanowym ${ }^{2}-\mathrm{w}$ domyśle świadczyło o przekonaniu członków Komitetu Zachodniego, iż w guberniach zachodnich Imperium tylko uczestnicy powstania posiadają majątki ziemskie. Było to oczywiście daleko idące uproszczenie, ale jak można przypuszczać, zadaniem tej kary miała być powszechność uderzenia w „мятежников”, a nie selektywny wybór rzeczywistych wrogów caratu ${ }^{3}$. Protesty Rosjan i Niemców nadbałtyckich posiadających majątki w sześciu guberniach litewsko-białoruskich doprowadziły rok później do wydania dwóch cyrkularzy Murawiewa z 5 i 6 lipca 1864 r., które zmniejszyły kontrybucję od majątków obywateli pochodzenia rosyjskiego lub z guberni nadbałtyckich z 10\% do 5\%, ale nie zwolniły ich całkowicie od obowiązku płacenia kontrybucji. Naciski na Wieszatiela musiały być jednak duże, skoro już 17 lipca 1864 r., czyli niecałe dwa tygodnie później kolejnym cyrkularzem jeszcze raz zmniejszył kontrybucję od tej kategorii ziemian do 2,5\% dochodu. W liście do ministra Aleksandra Zielenoja z sierpnia 1863 r. Murawiew skarżył się, że „obywatele Rosjanie nie rozumieją, że proponowana opłata od ich majątków nie jest kontrybucją, ale słuszną ofiarą aby pomóc

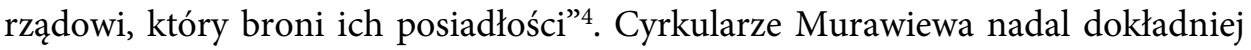
nie określały największej grupy ziemian dotkniętych kontrybucją, skupiając się na wydzieleniu z niej dwóch kategorii uprzywilejowanych, czyli osób „prawomyślnych” pochodzenia rosyjskiego lub z guberni nadbałtyckich. Druga część tej kategorii była niejasna i nieprecyzyjna, oczywiście chodziło o Niemców nadbałtyckich, ale przecież z guberni nadbałtyckich mogli pochodzić też Polacy.

Po raz pierwszy określenie „osoby polskiego pochodzenia” („лица польского происхождения") pojawiło się w zatwierdzonych przez Aleksandra II 5 marca 1864 r. „Przepisach o ulgach, przywilejach i pożyczkach pieniężnych obowiązujących przy zakupie ziem skarbowych oraz majątków prywatnych w guberniach zachodnich”. Paragraf 26 tych przepisów mówił: „Wszystkim nabywcom majątków korzystającym w jakikolwiek sposób z ulg, przywilejów i środków określonych w tych przepisach, jak i ich następców oraz zastępców, zabrania się je sprzedawać, zastawiać za długi lub w inny sposób zbywać osobom polskiego pochodzenia

${ }^{1}$ Wszystkie daty podawane są za kalendarzem juliańskim, czyli według tzw. starego stylu.

${ }^{2}$ Н. Цылов, Сборник распоряжений графа Михаила Николаевича Муравева по усмирению польского мятежа в Северо-Западных губерниях 1863-1864, Вильна 1866, s. 296-297.

${ }^{3}$ Co ciekawe, wcześniejsze rozporządzenie Murawiewa z 17 czerwca 1863 r. nakazywało pobranie w miastach $1 \%$ podatku od nieruchomości miejskich należących do „polskiej szlachty”, ibidem.

4 Z korespondencji Murawjewa do ministra Zielonoja w r. 1863, „Wschód Polski” 2 (1921), nr 8-9, s. 421-433.

5 Полное собрание законов Российской Империи (dalej: ПСЗ), Собрание 2, т. 39 (1864), № 40655, 40656. 
i Żydom"6. Termin ten, kilkakrotnie używany w tym dokumencie, jak i w jego uzupełnieniach ${ }^{7}$, został następnie powtórzony w zatwierdzonej 23 lipca $1865 \mathrm{r}$. „Instrukcji o sprzedaży gruntów skarbowych oraz majątków skonfiskowanych w guberniach zachodnich osobom narodowości rosyjskiej w tym kraju lub życzącym się tam osiedlić" oraz w pierwszym tzw. ukazie grudniowym z 10 grudnia 1865 r., zabraniającym „osobom polskiego pochodzenia” nabywania dóbr ziemskich wszelkimi sposobami (czyli poprzez darowiznę, kupno, dzierżawę i zapis testamentowy) ${ }^{9}$. Ukaz z 10 grudnia 1865 r. opierał się na ustaleniach „Specjalnej komisji najwyżej zatwierdzonej dla rozpatrzenia najpoddańszego sprawozdania ministra dóbr państwowych o środkach mających na celu osiedlenie elementu rosyjskiego w Kraju Zachodnim”, która obradowała w dniach od 29 listopada do 9 grudnia 1865 r. ${ }^{10}$ Komisja kierowana przez ks. Pawła Gagarina podjęła próbę sprecyzowania terminu „osoba polskiego pochodzenia”. Okazało się to nie takie proste, jak sądzili jej członkowie ${ }^{11}$. Gdy dyskutowano o kontrybucjach, konfiskatach i sekwestrach majątków uczestników powstania, o karaniu ich więzieniem i zsyłką, wszystko było jasne - przestępcy polityczni powinni zostać przykładnie ukarani. Problemy pojawily się, kiedy zaczęto mówić o przyszłej polityce państwa wobec polskiego ziemiaństwa i włączonych do Imperium ziem dawnej Rzeczypospolitej nazywanych w Rosji Krajem Zachodnim. Tutaj głosy członków komisji podzieliły się, choć różnice $\mathrm{w}$ ich poglądach nie dotyczyły samych celów, które chciano osiągnąć, a tylko form i narzędzi ich realizacji. Wymuszało to odpowiednie odniesienie się do nazewnictwa dotyczącego tej części społeczeństwa Ziem Zabranych, do której miały odnosić się planowane restrykcje. Generał Michał von Kaufman, Dymitr i Mikołaj Milutinowie i Zielenoj stali na stanowisku, aby zakazać osobom polskiego pochodzenia i wyznania rzymskokatolickiego kupowania ziemi w dziewięciu guberniach zachodnich. To oni właśnie podjęli się pierwszej próby

${ }^{6}$ Tekst w języku rosyjskim: „Всем приобретательям имений воспользовавшимся каким либо из установленых настоящим положением льготами и преимуществами или пособием равно их наследниками и переемниками прав запрещается продавать, закладывать или иным образом передавать те имения лицам польского происхождения и евреям", ibidem.

7 ПСЗ, Собрание 2, т. 41 (1868), отделение 2 (дополнение к т. 39 (1864), № 40 656a).

8 Ibidem, т. 40 (1865), № 41 957; т. 42 (1867), № 42328.

9 Ibidem, т. 40 (1865), ч. 2, № $42759,42760$.

10 Российский государственный исторический архив (dalej: РГИА), Ф. 1263 (Комитет Министров), оп. 4, д. 6 („Журнал особой коммисси Высочайше утвержденной для рассмотрения Всеподданнейшаго доклада Министра государственных имуществ о мерах к водворению русского элемента в Западном крае").

${ }^{11}$ Komisja składała się z 10 członków. Jej przewodniczącym był ks. Paweł Gagarin, pozostali to: gen. Michał von Kaufman - bohater wojny krymskiej (brat Konstantego von Kaufmana), minister wojny Dymitr Milutin, jego brat Mikołaj Milutin - jeden z twórców reformy uwłaszczeniowej, Aleksander Zielenoj - minister dóbr państwowych, Wiktor Panin - były, wieloletni minister sprawiedliwości, ks. Wasilij Dołgorukow - główny naczelnik III Oddziału Kancelarii Aleksandra II, hr. Piotr Wałujew - minister spraw wewnętrznych, hr. Michał Reutern - minister finansów, Dymitr Tołstoj - oberprokurator Świętobliwego Synodu. 
wyjaśnienia, kogo należy uznać za „osobę polskiego pochodzenia”. Oto dosłowne tłumaczenie tego wywodu: „Pod określeniem «osoby polskiego pochodzenia» nie należy rozumieć ogólnie katolików, a tylko Polaków i tych rodzimych mieszkańców guberni zachodnich, którzy przyswoili sobie polską narodowość. Chociaż z prawnego punktu widzenia wyrażenie to może wydawać się nieprecyzyjne, ale w praktyce, dotychczas w odniesieniu do osób, nie wywoływało żadnych wątpliwości. Między innymi, określenie to eliminuje całkowicie kwestię wyznania, gdyż byłoby to rzeczywiście niesprawiedliwym dokonywać dzielenia właścicieli według kryteriów religijnych, a nie politycznych" ${ }^{\prime 2}$. W tej definicji zniknął element dotyczący wyznania, z czym nie zgodził się przewodniczący ks. Gagarin, a wraz z nim Wiktor Panin, ks. Wasilij Dołgorukow, hr. Piotr Wałujew i hr. Michał Reutern. W swojej opinii odnieśli się oni do dwóch zagadnień: kto jest „уроженцем"13 Kraju Zachodniego i niemożności oddzielenia kwestii wyznaniowej od narodowości Polaków mieszkających na ziemiach litewsko-białoruskich. Prezentację stanowiska tej części komisji zaczęto bardzo górnolotnie, uznając, że Polakami można nazywać tylko urodzonych i żyjących w Królestwie Polskim, zaś urodzeni i żyjący w dziewięciu guberniach zachodnich, przywróconych Rosji, powinni być bez żadnej wątpliwości traktowani jako rodzima ludność rosyjska („русские уроженцы”). Pogląd ten bardziej odzwierciedlał pragnienia polityczne tej grupy wysokich urzędników państwa rosyjskiego niż stan rzeczywisty, lecz jednocześnie wskazywał na sposób myślenia osób, które przecież przygotowały jeden z najważniejszych antypolskich aktów prawnych epoki Aleksandra II. Wyjaśnienie tego poglądu łączyło się z drugą kwestią, a mianowicie akceptacją tego, że do czasów obecnych cechą charakterystyczną polskiego pochodzenia osób urodzonych nie w Królestwie Polskim, a w Cesarstwie była przynależność do wyznania katolickiego ${ }^{14}$. Dlatego w pełni zaakceptowali oni definicję sformułowaną przez czterech członków komisji, „która pozostaje w mocy, lecz według przekonania przewodniczącego i czterech członków zakaz kupowania majątków w guberniach zachodnich będzie w swojej istocie odnosił się do wszystkich rodzimych mieszkańców Kraju Zachodniego wyznających wiarę katolicką"15.

12 Ten fragment w języku rosyjskim: „Под выражением «лица польского происхождения» нужно понимать не вообще католиков а только польяков и тех западных уроженцев, которые усвоили себя польскую национальность. Хотя в юридическом отношении выражение это может показатся не точным, но на практике в применении к лицам оно не возбуждило доселе никаких сомнений. Между тем, выражением этим устраняется вполне вопрос о вероисповедании, так как было бы совершенно несправедливо делать различие между владельцами не по политическим а по религиозным соображениям”, РГИА, Ф. 1263, оп. 4, д. 6 , л. 18.

13 Słowa tego nie można przetłumaczyć jednoznacznie, gdyż nie chodzi w nim tylko o „urodzenie się w Kraju Zachodnim”, lecz także o uznawanie „Kraju Zachodniego” (a faktycznie Ziem Zabranych") za ziemię rodzinną, ojczystą.

14 РГИА, Ф. 1263 , оп. 4, д. 6, л. 30.

15 Ibidem. 
I jakkolwiek ukaz z 10 grudnia 1865 r. mówił tylko o „osobach polskiego pochodzenia", nie dodając do tego określenia wyznacznika religijnego, to jak miała pokazać przyszłość, uwaga dotycząca wyznania, sformułowana w opinii ks. Gagarina i czterech członków komisji, zachowała swoją aktualność do końca istnienia caratu. Dokładnie cztery lata po wydaniu ukazu z 10 grudnia 1865 r. minister dóbr państwowych Zielenoj odpowiedział na pytania generała-gubernatora wileńskiego, kowieńskiego i grodzieńskiego Aleksandra Potapowa dotyczące stosowania ukazu z 10 grudnia 1865 r. wobec osób polskiego pochodzenia przyjmujących prawosławie. W liście $\mathrm{nr} 20 \mathrm{z} 10$ grudnia 1869 r. minister napisał, że przyjęcie prawosławia przez osobę polskiego pochodzenia nie może być prawnym powodem do niezastosowania wobec niej przepisów obowiązujących od 10 grudnia $1865 \mathrm{r} .{ }^{16}$ Minister podał także, kiedy może nastąpić „zamiana” narodowości polskiej na rosyjską: „Jeśli potomkowie tych osób [czyli zmieniających wyznanie - R.J.] będący wyznania prawosławnego przyswoją sobie, z upływem czasu, narodowość rosyjską, dokładnie tak jak przodkowie wielu obecnych polskich ziemian w Kraju Zachodnim będący wcześniej Rosjanami stopniowo przyswoili sobie narodowość polską po przejściu z prawosławia na katolicyzm, to na wszystkie te zmiany, dla rzeczywistego osiągnięcia tej przemiany narodowości, potrzeba niemało czasu, po upłynięciu którego osoby te faktycznie zostaną Rosjanami i wówczas ostatecznie odżegnując się od języka polskiego, przestaną być uważane za osoby polskiego pochodzenia" ${ }^{\prime 1}$.

Kolejne przepisy ograniczające polskie ziemiaństwo w obrocie ziemią z 27 grudnia $1884 \mathrm{r}^{18}$ i 2 lutego $1891 \mathrm{r} .{ }^{19}$ nic nie zmieniły w odniesieniu, jak pisze Leonid Gorizontow, „do planu sprecyzowania obiektu dyskryminacji” ${ }^{20}$. Dopiero w $1886 \mathrm{r}$. prawnie usankcjonowano to, co w praktyce istniało od grudnia 1865 r., czyli prawo generałów-gubernatorów i gubernatorów do podejmowania ostatecznej decyzji,

16 „Доклад начальника VII отделения Департамента общих дел Министерства внутренних дел, статского советника Строльмана по вопросу о том кого следует считать „лицом польского происхождения”, РГИА, Ф. 1278 (Канцелярия Государственной Думы), оп. 2, д. 1171 (Об применени положения о земских учреждениях 12 июня 1890 г. к губерниям: Витебской, Волынской, Киевской, Минской, Могилевской и Подольской 22 I 1910 - 14 III 1911 г.), л. 102.

17 „Если потомки этих лиц будучи православного исповедания усвоят себе, со временем, русскую национальность, точно также как предки многих нынешних польских помещиков Западного края, бывшие некогда русскими усвоили себе постепенно польскую национальность после перехода из православия в латинство, то все же дпя действительного достижения этой перемены национальности нужно немало времени по прошестви коего лица эти будучи русскими на самом деле и окончательно отрешився от польского языка, перестанут считатся лицами польского происхождения", ibidem.

18 ПСЗ, Собрание 3, т. 4 (1884), № 2633. Zabroniono dzierżawienia ziemi dłużej niż przez 12 lat oraz zakazano brania w zastaw wszelkich majątków poza miastami i miasteczkami.

19 Ibidem, т. 11 (1891), № 7422. Zabroniono „osobom polskiego pochodzenia” oddawania majątków w dożywotnie użytkowanie innym Polakom.

20 Л.Е. Горизонтов, Парадоксы имперсеой политики. Поляки в России и русские в Польше, Москва 1999, s. 102. Por. też: R. Jurkowski, Jeszcze o „paradoksach” imperialnej polityki Rosji w guberniach zachodnich po powstaniu styczniowym, „Echa Przeszłości” 14 (2013), s. 93-107. 
komu udzielić lub odmówić zgody na zakup ziemi. Rozporządzenie Komitetu Ministrów z 1 listopada 1886 r. czyniło wszelkie transakcje gruntami ziemskimi zależnymi od najwyższych przedstawicieli władz administracyjnych. Wydanie tzw. świadectwa na kupno ziemi było uwarunkowane wyłącznie decyzją tych urzędników. Dotknęło to najbardziej włościan wyznania katolickiego, których rozporządzenie Komitetu Ministrów z 13 czerwca 1868 r. zwalniało z rygorów ukazu z 10 grudnia 1865 r., czyli nie uznawano ich za „osoby polskiego pochodzenia”. Po wydaniu rozporządzenia z 1 listopada 1886 r. władze zaczęły odmawiać włościanom pozwoleń na zakup ziemi. Stan taki trwał do 27 stycznia 1901 r., gdy Ministerstwo Spraw Wewnętrznych (MSW) poleciło gubernatorom wydawać włościanom wyznania rzymskokatolickiego świadectwa na zakup ziemi o maksymalnym areale 60 dziesięcin na rodzinęę .

Jak bumerang w powyższych aktach prawnych wracała kwestia wyznania katolickiego jako podstawowego wyróżnika „osób polskiego pochodzenia”, choć na początku wieku coraz głośniej zaczęto mówić o innym traktowaniu, w przepisach dotyczących nabywania ziemi, chłopów narodowości litewskiej wyznających katolicyzm. Widać to wyraźnie w ukazie z 12 grudnia 1904 r. „O perspektywach udoskonalenia porządku państwowego”, którego punkt 7 mówił o „rewizji ustaw ograniczających obcoplemieńców"22. Komitet Ministrów polecił wybranym urzędnikom w ministerstwach (spraw wewnętrznych, finansów, oświaty) dokonanie przeglądu istniejącego ustawodawstwa, $\mathrm{z}$ tym, aby wśród przepisów zachowano przede wszystkim te, które sprzyjają „ważnym interesom państwa i przynoszą jawne korzyści dla narodu rosyjskiego"23. Efektem ich pracy był dokument przedstawiający decyzje Komitetu Ministrów (tzw. особой журнал), zatwierdzony 1 maja 1905 r. przez Mikołaja II. Uznano w nim, że wśród katolików mogą być także osoby niepolskiego pochodzenia, których nie należy ograniczać w zakupie majątków ${ }^{24}$. Jednocześnie Komitet Ministrów po raz kolejny stwierdzał, że wobec nieokreślenia w prawie dokładnych cech pojęcia "polskie pochodzenie” 25 decyzję o zgodzie na zakup ziemi mogą udzielać wyłącznie urzędnicy miejscowej wyższej administracji w osobach generałów-gubernatorów i gubernatorów, gdyż tylko oni mogą rozpatrywać podobne sprawy, „opierając się na istocie ich politycznego, a nie prawniczego charakteru”26. Uznano, że tylko władze miejscowe posiadają odpowiednie środki do upewnienia

${ }^{21}$ R. Jurkowski, Ziemiaństwo polskie Kresów Pólnocno-Wschodnich 1864-1904. Działalność spoŁeczno-gospodarcza, Warszawa 2001, s. 113.

22 Законодательные акты переходного времени. 1904-1908 г2. Сборник законов, манибестов, указов Правительсвующего Сенату, рескриптов и положений комитета министров, относящихся к преобразованию государственного строя России, с приложением алфавитного предметного указателя, Изд. 3-е, пересм. и доп. по 1 сентября 1908 года, ред. пр.-доц. Н.И.Лазаревского, Санкт-Петербург 1909, s. 3-6.

${ }^{23}$ РГИА, Ф. 1278 (Канцелярия Государственной Думы), оп. 2, д. 1171, л. 103.

${ }^{24}$ Ibidem.

${ }^{25}$ Ibidem.

${ }^{26}$ Ibidem. 
się w tym, czy proszący nie jest Polakiem lub spolonizowanym (ополяченым) Litwinem, którego $\mathrm{w}$ tym zakresie należy utożsamiać $\mathrm{z}$ Polakiem ${ }^{27}$. W dokumencie wyraźnie zastrzeżono, aby nie udzielać notariuszom uprawnień do decydowania, kto jest, a kto nie jest „osobą polskiego pochodzenia” - stanowiło to zapewne pokłosie wielu skarg gubernatorów na notariuszy wystawiających za łapówki antydatowane dokumenty dotyczące praw własności czy umów zastawnych i dzierżawnych.

$\mathrm{W}$ aktach prawnych z początku XX w. zaczyna być wyraźnie widoczny element narodowości jako coraz istotniejszy czynnik służący identyfikacji osoby składającej podanie o zgodę na kupno ziemi. Przepisy z 1 listopada 1886 r., dające generałom-gubernatorom i gubernatorom prawo do "dyskrecjonalnego", lecz ostatecznego decydowania, kto może kupić ziemię w guberniach zachodnich, formalnie zniósł ukaz z 1 maja 1905 r. Odsyłał on wszystkich skarżących się do Senatu Rządzącego, co jeszcze bardziej wydłużyło biurokratyczną drogę przy odwołaniach od decyzji władz lokalnych, gdyż Senat kierował skargi do ministerstw (spraw wewnętrznych lub finansów), te zaś do guberni i wszystko ponownie wracało do Senatu. W tym czasie podjęto kolejną próbę uściślenia określenia terminu „osoba polskiego pochodzenia”. Minister finansów zwrócił się do generałów-gubernatorów i gubernatorów z Kraju Zachodniego, aby jako miejscowi obserwatorzy życia kresowego wyrazili swój pogląd, kogo należy zaliczyć do „osób polskiego pochodzenia”. Zdecydowana większość raportów nie odbiegała od opinii sprzed kilkudziesięciu lat. Jak odnotował Konstanty Strolman ${ }^{28}$, naczelnik Oddziału VII Departamentu Spraw Ogólnych MSW: „Niektóre opinie identyfikują polskie pochodzenie z przynależnością do kościoła rzymsko-katolickiego: zgodnie z tym określeniem każdy katolik jest Polakiem"29. Tylko jeden gubernator (niestety źródło nie podaje jego nazwiska ani guberni, którą rządził) pokusił się o głębszą próbę definicji. Napisał: „Za osobę polskiego pochodzenia uważa się tego kto urodził się z polskich rodziców i sam jest katolikiem. Przyjęcie prawosławia przez niego, lub jego rodziców nie zmienia jego polskiej narodowości. Tylko pochodzenie wnioskodawcy wyznającego wiarę prawosławną od rodziców urodzonych w prawosławiu, można uznawać za dostateczną podstawę do uznania wnioskodawcy za osobę niepolskiego pochodzenia"30. Warto tutaj zwrócić uwagę, że przynależność wyznaniowa jako wyznacznik polskości lub niepolskości była znacznie rozciągnięta w czasie: także rodzice muszą urodzić się w rodzinie prawosławnej, czyli jeśli dana osoba jest prawosławną w trzecim pokoleniu, to dopiero wtedy może być uznana za „niepolskiego pochodzenia”. Natomiast w przypadku Polaka gubernator łączył dwie kwestie

27 Ibidem.

${ }^{28}$ Jego memoriał, wraz z komentarzem i informacjami o autorze, opublikowałem w 2017 r.: Czy każdy katolik to Polak? - kresowe, narodowo-religijne dylematy rosyjskiej biurokracji $w$ dokumencie Ministerstwa Spraw Wewnętrznych z 1910 roku, „Studia z Dziejów Rosji i Europy Środkowo-Wschodniej" 52 (2017), z. 2, s. 223-239.

${ }^{29}$ Ibidem, s. 235.

30 Ibidem, s. 236. 
- przynależności narodowej rodziców i automatycznie ich dzieci oraz wyznanie katolickie tych dzieci. W takiej sytuacji przejście na prawosławie niczego nie zmieniało.

Zmianie ulegała jednak polityka państwa rosyjskiego wobec innych niż rosyjska narodowości zamieszkujących ogromne Imperium. Idea lojalności wobec tronu i dynastii, akceptowana jeszcze w epoce Aleksandra II, za czasów jego następcy okazała się już niewystarczająca w zestawieniu z rosnącym nacjonalizmem rosyjskim i procesami administracyjnej rusyfikacji, szczególnie narodów żyjących na zachodnich kresach państwa. Wzrost świadomości narodowej wśród Rosjan szedł niestety $\mathrm{w}$ parze $\mathrm{z}$ akceptowanymi i rozwijanymi $\mathrm{w}$ elitach władzy tendencjami rusyfikacyjnymi. Do tego potrzebne jednak było dokładniejsze nazwanie przeciwnika czy ściślej - przedmiotu polityki rusyfikacyjnej. Gorizontow zawarł to zjawisko w słowach: jak znaleźć Polaka? Po pierwszym i jedynym spisie ludności Rosji, zwanym spisem jednodniowym z 28 stycznia 1897 r., „szukanie Polaka” było już prostsze - występowały tam kategorie narodowościowe obok wyznaniowych.

W końcu XIX w. i na początku XX w. do polityki Rosji wobec narodów kresowych doszedł jeszcze jeden czynnik. Proces odradzania się narodu litewskiego, zapoczątkowany w latach osiemdziesiątych XIX w. i bacznie obserwowany przez władze, wskazał na możliwość użycia nowego elementu polityki „dziel i rządź”, czyli coraz ostrzejszego polsko-litewskiego konfliktu narodowego dziejącego się wewnątrz jednego wyznania, zwalczanego wszak przez prawosławną Rosję. Można już było przeciwstawiać sobie nie tylko chłopa i pana, ale także Litwina - chłopa i katolika Polakowi - ziemianinowi i katolikowi. Skłaniało to do rozważań o zmianie części składowych definicji „osoby polskiego pochodzenia”. Dlatego radca państwowy (V rangi cywilnej) Strolman po obszernym opisie konfliktu polsko-litewskiego w kościołach tak w 1909 r. proponował opisać osobę polskiego pochodzenia: „Moim zdaniem polską narodowość należy określać na podstawie używania języka polskiego w życiu codziennym. Poza tym nie odrzucając rzeczywistego związku między katolikami a polonizmem w Kraju Zachodnim, sądzę, że za Polaka należy uważać tego, kto używa języka polskiego w życiu codziennym i przy tym wyznaje wiarę katolicką"31.

Uwagi naczelnika Oddziału VII Departamentu Spraw Ogólnych MSW miały być wykorzystane podczas wprowadzania ziemstw - modelu z 1890 r. do sześciu guberni zachodnich. Rychło jednak okazało się, że wśród ziemian stanowiących podstawową grupę radnych ziemskich jest tak mało Rosjan, że konieczne stało się wymyślenie kurii narodowościowych dzielących radnych według narodowości. Taki podział, w którym liczni polscy ziemianie wybierali mniejszą liczbę radnych niż nieliczni Rosjanie, czynił zbędne szczegółowe oddzielanie Polaków od Rosjan na podstawie opracowanych definicji „osoby polskiego pochodzenia”. Była ona także niepotrzebna, gdy liczono Polaków przed podziałem na kurie narodowościowe. Aby zmniejszyć ich liczbę, zastosowano wszelkie sposoby zgodnie z powiedzeniem: „istnieje nieprawda, kłamstwo i statystyka”.

31 Ibidem, s. 237. 


\section{Wnioski}

Problem z określeniem cech charakteryzujących „osoby polskiego pochodzenia” związany był przede wszystkim ze sprawami własności ziemskiej, czyli dotyczył sfery materialnej. W innych dziedzinach życia, np. przy zapisach do szkół średnich czy przy wstępowaniu na uczelnie, ograniczano się do deklaracji kandydata dotyczącej narodowości i wyznania, oczywiście wraz ze świadectwem „prawomyślności”. W odniesieniu do majątków ziemskich decyzja, kogo uznać albo nie uznać za „osobę polskiego pochodzenia”, zawierała co najmniej kilka ważnych elementów natury politycznej i ekonomicznej. Po pierwsze, gdy był to Rosjanin lub nie-Polak i niekatolik - otrzymując zgodę na kupno majątku, zwiększał liczbę rosyjskich właścicieli ziemskich (i obszaru ziemi przez nich posiadanej) na Ziemiach Zabranych. Po drugie, mógł zostać urzędnikiem w najróżniejszych instytucjach państwowych, po 1903 r. samorządowych, a po 1905 r. mógł być wybierany do obu izb przedstawicielskich rosyjskiego parlamentu. W aspekcie ekonomicznym istotne było także i to, że tzw. majątki instrukcyjne (na które składały się głównie dobra skonfiskowane za udział w powstaniu) sprzedawano na wyjątkowo dogodnych warunkach kredytowych, wszak odnosiło się to do tego, co wcześniej nie należało do państwa rosyjskiego - i dlatego termin „osoba polskiego pochodzenia” miał zapobiec sytuacji, gdyby Polak lub katolik kupił taki majątek. Problem ten stracił na ostrości po 1905 r., gdy pozwolono „osobom polskiego pochodzenia” na kupowanie ziemi od „osób polskiego pochodzenia”. Świadectwo nienależenia do powyższej kategorii było po 1905 r. potrzebne tylko wtedy, gdy Polak chciał kupić ziemię od Rosjanina.

Wcale nie wiadomo, czy władzom rosyjskim w planowaniu systemu represji po powstaniu styczniowym takie oddzielenie narodowości od wyznania było potrzebne. Co więcej, czy w ogóle potrzebowali precyzyjnego określenia składników stanowiących o tym, czy rzeczywiście mają do czynienia $\mathrm{z}$ „osobą polskiego pochodzenia”. Prawa ograniczające Polaków powinny przecież zrealizować co najmniej dwa zadania, z których „ukaranie miatieżników” za podniesienie ręki na Imperium wcale nie było najważniejsze. Główny cel, o czym wprost pisano w dziesiątkach ukazów monarszych, zarządzeniach ministerstw, wyjaśnieniach Senatu i cyrkularzach gubernatorów, stanowiło zwiększenie rosyjskiego stanu posiadania (czyli liczebności Rosjan i wielkości posiadanego przez nich areału) na ziemiach zabranych Rzeczypospolitej poprzez osiedlanie tam Rosjan należących do różnych grup społecznych ${ }^{32}$. W takiej sytuacji używanie kryterium religijnego lub łączenie narodowości $\mathrm{z}$ wyznaniem znacznie ułatwiało proces rusyfikacji dziewięciu

$32 \mathrm{O}$ osadnictwie chłopów rosyjskich w guberni kowieńskiej po powstaniu styczniowym pisałem w artykule: Rosjanie wśród Litwinów w XIX wieku jako narzędzie rusyfikacji Ziem Zabranych. Przyczynek do dziejów osadnictwa chłopów rosyjskich w guberni kowieńskiej po powstaniu styczniowym, w: Migracje a tożsamość narodowa mieszkańców Europy Wschodniej w XIX i na początku XX wieku, red. D. Michaluk, Ciechanowiec 2016, s. 81-102. 
zachodnich guberni Rosji, bo katolikiem był także chłop i drobny szlachcic narodowości litewskiej czy białoruskiej ${ }^{33}$.

Tezę z poprzedniego wniosku potwierdza praktyka wykorzystywania tytułowego terminu $\mathrm{w}$ działalności generałów-gubernatorów i gubernatorów w guberniach zachodnich, którzy od 1 listopada 1886 r. otrzymali od Komitetu Ministrów zatwierdzone przez cara rozporządzenie dające im prawo do „uznaniowego ale dyskretnego decydowania komu wydać pozwolenia na nabywanie ziemi w Kraju Zachodnim" "34. Dotyczyło to osób zarówno rosyjskiego, jak i nierosyjskiego pochodzenia. Rozporządzenie to formalnie zostało zniesione w 1905 r., a w praktyce ( $w$ formie opinii gubernatorów o kandydacie zamierzającym kupić ziemię) działało do końca istnienia caratu i było $z$ jednej, prawniczej strony świadectwem słabości prawodawstwa państwowego niemogącego uporać się z jednym ogólnym pojęciem stosowanym wszak w normatywnych aktach prawnych. Natomiast z drugiej strony jednoznacznie potwierdzało fakt, iż dla aparatu biurokratycznego państwa priorytetem był proces wchłaniania Ziem Zabranych do organizmu Imperium Rosyjskiego i w tym celu nie wahano się wydawać nieprecyzyjnych aktów prawnych lub całkowicie stojących w kolizji z wcześniejszym ustawodawstwem.

\section{"Person of Polish Origin". The Terminological and Legal Aspects of Reprisals after the January Uprising in the Taken Lands}

\section{Abstract}

The development of the system of reprisals against the Polish landed gentry in the Taken Lands after the fall of the January Uprising (1864) resulted in the need to legally define the subject of system restrictions by the Russian state. It was therefore necessary to determine who was a "person of Polish descent", and devise a method of separating such a person from other inhabitants of a multinational and multi-religious society living in the former Commonwealth lands taken by Russia. The purpose was to determine who should pay the contribution imposed on the Polish population for participating in the January Uprising (1863-64) and who should be subject to restrictions in the land sales in the Western guberniyas. This was done not only by special committees (Western Committee), and special commissions (e.g. for the Settlement of the Russian Element in the Western Country of 1865), but also state ministries (mainly the Ministry of the Interior), successive state cabinets (especially under Tsar Alexander III), and governor-generals from Vilno and Kiev as well as more zealous Russifiers in the persons of governors from nine Lithuanian-Belarusian-Ukrainian guberniyas. This task turned out to be too difficult for members of the Russian bureaucratic machine; in practice, the ethnic differentiator (sometimes based on the everyday language) was combined with the religious one (Catholic). So the "person of Polish descent" was usually a Pole who used Polish at home and professed Catholic faith. Problems appeared when the landowner was of Polish nationality, he spoke Polish, but he was not Catholic, e.g. Orthodox, or he was Catholic, he spoke Polish, but

\footnotetext{
${ }^{33}$ Przepisy dotyczące nabywania ziemi przez chłopów wyznania katolickiego szczegółowo przedstawiłem w książce Ziemiaństwo polskie..., s. 112-115.

34 РГИА, Ф. 1278, оп. 2, д. 1171, л. 102.
} 
he considered himself a German, or worse, a Russian! In the face of such cases, which were not uncommon, everything (i.e. paying contributions and the right to trade in land) depended on the decision of an individual governor.

\section{"Лицо польского происхождения" • Терминологически-юридический аспект репрессий после Январского восстания на Отобранных землях}

\section{Аннотация}

Создание системы репрессий в отношении польских помещиков на Отобранных землях после падения Январского восстания, вызвало необходимость в юридическом определении предмета, подверженного системным ограничениям со стороны российского государства. Следовательно, надо было определить, кто является «лицом польского происхождения» и как выделить такое лицо из числа других жителей, принадлежавших к многонациональному и многоконфессиональному обществу, населявшему земли, отобранные Россией у бывшей Речи Посполитой. Речь шла о том, кто должен платить контрибуцию, которой обложили польское население за участие в восстании и на кого должны распространяться ограничения в приобретении земель в Западных губерниях. Этим занимались не только особые комитеты (Западный комитет), особые комиссии (напр. о мерах водворения в Западном крае русского элемента в 1865 г.), но и министерства (главным образом Министерство Внутренних Дел), отдельные правительства (особенно при Александре III), как и Виленские и Киевские генерал-губернаторы, а также некоторые усердствующие русификаторы из числа губернаторов девяти литовско-белоруско-украниских губерний. Эта задача оказалась слишком сложной для представителей российской бюрократической машины - на практике соединялись признаки этнический (иногда опиравшийся на повседневный язык) с конфессиональным (католик). Следовательно, «лицом польского происхождения» был обычно поляк, пользующийся дома польским языком и исповедующий католицизм. Дилеммы появлялись, когда помещик польской национальности, говорил на польском, но не был католиком, а напр. православным, или был католиком, говорил на польском, но считал себя немцем или еще хуже - русским! В таких случаях, ничуть нередких, все (то есть оплата контрибуции и право приобретения земли) зависело от решения данного губернатора.

\section{Bibliografia}

\section{Źródła}

Российский государственный исторический архив (РГИА)

Ф. 1263 (Комитет Министров), оп. 4, д. 6

Ф. 1278 (Канцелярия Государственной Думы), оп. 2, д. 1171

Полное собрание законов Российской Империи, Собрание 2, т. 39 (1864), № 40655, 40656; т. 40 (1865), № 41 957; т. 40 (1865), ч. 2, № 42 759, 42 760; т. 41 (1868), отделение 2 (дополнение к т. 39 (1864), № 40 656а; т. 42 (1867), № 42 328; Собрание 3, т. 4 (1884), № 2633; т. 11 (1891), № 7422. 


\section{Opracowania}

Jurkowski R., Czy każdy katolik to Polak? - kresowe, narodowo-religijne dylematy rosyjskiej biurokracji $w$ dokumencie Ministerstwa Spraw Wewnętrznych $z 1910$ roku, „Studia z Dziejów Rosji i Europy Środkowo-Wschodniej” 52 (2017), z. 2, s. 223-239.

Jurkowski R., Jeszcze o „paradoksach” imperialnej polityki Rosji w guberniach zachodnich po powstaniu styczniowym, „Echa Przeszłości” 14 (2013), s. 93-107.

Jurkowski R., Rosjanie wśród Litwinów w XIX wieku jako narzędzie rusyfikacji Ziem Zabranych. Przyczynek do dziejów osadnictwa chłopów rosyjskich w guberni kowieńskiej po powstaniu styczniowym, w: Migracje a tożsamość narodowa mieszkańców Europy Wschodniej w XIX i na początku XX wieku, red. D. Michaluk, Ciechanowiec 2016, s. 81-102.

Jurkowski R., Ziemiaństwo polskie Kresów Północno-Wschodnich 1864-1904. Działalność społeczno-gospodarcza, Warszawa 2001.

Z korespondencji Murawjewa do ministra Zielonoja w r. 1863, „Wschód Polski” 2 (1921), nr 8-9, s. 421-433.

Горизонтов Л.Е., Парадоксы имперсеой политики. Поляки в России и русские в Польше, Москва 1999.

Законодательные акты переходного времени. 1904-1908 гг. Сборник законов, манифестов, указов Правительсвующего Сенату, рескриптов и положений комитета министров, относящихся к преобразованию государственного строя России, с приложением алфавитного предметного указателя, Изд. 3-е, пересм. и доп. по 1 сентября 1908 года, ред. пр.-доц. Н.И. Лазаревского, Санкт-Петербург 1909.

Цылов Н.И., Сборник распоряжений графа Михаила Николаевича Муравева по усмирению польского мятежа в Северо-Западных губерниях 1863-1864, Вильна 1866.

Roman Jurkowski, prof. dr hab., kierownik Zakładu Europy Wschodniej Instytutu Historii i Stosunków Międzynarodowych Uniwersytetu Warmińsko-Mazurskiego w Olsztynie, historyk. Jego zainteresowania naukowe skupiają się na dziejach ziemiaństwa polskiego z Ziem Zabranych, ze szczególnym uwzględnieniem historii polskiej myśli politycznej na tych obszarach i działalności Polaków w życiu parlamentarnym Imperium Rosyjskiego (roman.jurkowski@uwm.edu.pl).

Roman Jurkowski, Prof. dr. hab. at the Institute of History and International Relations of the University of Warmia and Mazury in Olsztyn (head of the Department of Eastern Europe), historian. His scientific interests focus on the history of the Polish landed gentry from the so-called Taken Lands, with particular emphasis on the history of Polish political thought in these areas and the activities of Poles in the parliamentary life of the Russian Empire (roman. jurkowski@uwm.edu.pl). 